DOI: $10.15290 /$ bsl.2014.05.11

\title{
Ewa Nawrocka
}

Uniwersytet Gdański

e-mail: filen@univ.gda.pl

\section{Maria Dąbrowska w Jugosławii}

Maria Dąbrowska była w Jugosławii trzy razy ${ }^{1}$. Opisywała ją w listach do towarzysza życia Stanisława Stempowskiego, w dziennikach ${ }^{2}$, w reportażu drukowanym w "Wiadomościach Literackich" ${ }^{3}$ i w opracowanym na ich podstawie tekście w Pismach rozproszonych, zatytułowanym Podróż do Jugosławii ${ }^{4}$. Utrwalała jej wizerunek $\mathrm{w}$ pamięci, $\mathrm{w}$ zapiskach, na rysunkach. Przywoływała w snach.

Dąbrowska podróżowała dużo, jeszcze jako studentka przed pierwszą wojną światową, potem $\mathrm{w}$ dwudziestoleciu międzywojennym odbyła kilka istotnych podróży na Północ i na Południe Europy. Każda była dla niej jednocześnie doświadczeniem nowej przestrzeni, nowego, innego świata, zdobywaniem o nim wiedzy, jak i bodźcem inspirującym do krystalizowania się samowiedzy. Podróżnicze życie w ruchu, doświadczanie zmienności zewnętrznego świata współtworzyły procesualny podmiot, migotliwy, zmieniający się, rozpisany na mnogość i bogactwo wrażeń, zmysłowych doznań,

1 1934, 1936, 1960.

2 M. Dąbrowska, Dzienniki, t. 1-4, wybór, wstęp i przypisy T. Drewnowski, Warszawa 1988; tejże, Dzienniki powojenne 1945-1965, t. 4, Warszawa 1997. Dalej jako Dz., numer tomu i strony bezpośrednio po cytacie.

3 M. Dąbrowska, Polacy w Jugosławii, „Wiadomości Literackie” 1935, nr 16; Na wyspie Rab, „Wiadomości Literackie” 1936, nr 38; Czerwiec na Rabie, „Wiadomości Literackie” 1936, nr 46.

4 M. Dąbrowska, Podróż do Jugostawii, w: tejże, Pisma rozproszone, red. i przypisy E. Korzeniewska, t. 1, Kraków 1964. 
spontanicznych reakcji na bodźce, pogłębionych refleksji, twórczych myśli. Reagowała tak, jakby rzeczywistość była dla niej „nagłym przepływem sensorycznych wyglądów, a nie umysłowym porządkiem ponad nimi" 5 .

W podróży rozpoznawała swoje wewnętrzne rozdarcie między przyrodzoną zdolnością do zachwytu, witalistyczną zachłannością doznawania niezmierzonego bogactwa materii życiowej a "faustyczną chwilą" podszytą odczuwaniem tragizmu istnienia.

Zadłużona w filozoficznej myśli mistrza swej młodości Edwarda Abramowskiego przyjmowała jako pewnik, że istnieje coś takiego, jak „artystyczne doznawanie świata" ${ }^{6}, \mathrm{w}$ którym decydującą rolę odgrywa "reagująca potęga duszy”. W tym "artystycznym doznawaniu świata” jako narzędzia poznania wykorzystywane są intuicja, pamięć, wyobraźnia i uczucia, słowem całe bogactwo życia psychicznego, które, co istotne, fundowało się na doznaniach zmysłowych: wzrokowych, słuchowych, węchowych, dotykowych, zanurzało $\mathrm{w}$ "strumieniu zmysłowych wyglądów" 7 .

Niemniej Dąbrowska przygotowując do druku w „Wiadomościach Literackich" swoje "prywatne" notatki z podróży do Jugosławii oczyszczała tekst z elementów zanadto, jej zdaniem, osobistych, zindywidualizowanych, ograniczających obiektywizm obrazu świata. Była z pewnością przekonana, że gatunek-podróż w wersji reportażowej wymaga maksymalnego zobiektywizowania obrazu świata, co $\mathrm{w}$ praktyce oznaczało poddanie spontanicznego i subiektywnego opisu rygorom intelektualnym, uporządkowaniu stylistycznemu, kompozycyjnej strategii. Jakby to świat był ważniejszy od jego doświadczania, opis od wyrażania, od-twarzanie wizerunku od tworzenia go.

Bliskie Dąbrowskiej Mickiewiczowskie „widzę i opisuję” kładzie oczywiście nacisk na wzrokowy odbiór świata, przy czym „widzę" to nie tylko fizjologiczna kategoria wzrokowego rejestrowania zewnętrznej rzeczywistości, ale i kategoria poznawcza uwikłana w kulturowe klisze, a na poziomie "opisuję" - w literackie konwencje. „Widzę" nie ogranicza się nigdy wyłącz-

5 S. Schwartz, The Matrix of Modernism. Pound, Eliot, and Early Twentieth-Century Thought, Princeton, New Jersey 1985, s. 12. Cyt. za: B. Sienkiewicz, Literackie "teorie widzenia” w prozie dwudziestolecia międzywojennego, Poznań 1992, s. 10.

6 M. Dąbrowska, O „Panu Tadeuszu”. Z powodu artykułu J. N. Millera, „Wiadomości Literackie” 1925, nr 15, przedruk w: M. Dąbrowska, Pisma rozproszone, red. i przypisy E. Korzeniewska, t. 2, Kraków 1964, s. 22.

7 Jest to termin przywoływanego przez B. Sienkiewicz S. Schwartza. Zwraca on uwagę, że „Pojęciowe abstrakcje są [...] narzędziami, dzięki którym narzucamy czysto rozumowy porządek na świat wokół nas. A ten świat istnieje jako strumień zmysłowych wyglądów, jako sensoryczny potok, który staramy się uporządkować rozumowo" (B. Sienkiewicz, Literackie "teorie widzenia", s. 174). 
nie do wrażeń wzrokowych. Ludzie, rzeczy, miejsca i przestrzenie ewokują pozostałe wrażenia zmysłowe, nawet gdy nie zostały wprost nazwane.

Trzy podróże do Jugosławii, ściślej trzy różne gatunkowo formy zapisu tych podróży (prywatne listy, dzienniki, reportaż), ujawniają fakt napięcia między podmiotową prawdą bycia tu i teraz, którą Dąbrowska chce wyrazić, a przedmiotowością bytu, którą chce obiektywnie przedstawić. Dąbrowska, zwłaszcza w listach i w dziennikach, daje wyraz doświadczeniu bycia w konkretnym miejscu świata w określonym czasie. To doświadczenie bardzo osobiste, własne, nasycone emocjami, jeszcze nie w pełni uporządkowane intelektualnie. Pisarka pozwala sobie na spontaniczne odsłonięcie doznawanych wrażeń zmysłowych, tego, co widzi, słyszy, dotyka, smakuje. Pozwala to jej dotrzeć do istoty własnej osobowości. Jej centrum stanowią potrzeba i umiejętność „doznawania intensywności życia." Towarzyszy im z reguły zachwyt, empatia i sympatia wobec istnienia, otwartość na niezmierzone bogactwo materii życiowej.

Już w trakcie młodzieńczych wędrówek po Belgii, a potem podróży na Północ, do Finlandii (1927), starała się Dąbrowska obserwować świat bez uprzedzenia i pierwotnych poznawczych założeń, z ciekawością dziecka, reagującego spontanicznie na rzeczy i zjawiska nowe i nieznane. Zauważyła, że jej wyobrażenia o rzeczach są blade i ubogie w porównaniu z życiem, które ją zawsze olśniewa. We Włoszech (1934) pozwoliła sobie zignorować własną, niemałą erudycję, intelektualny dystans do rzeczywistości, wiedzę i filozoficzne refleksje, porzucając je na rzecz spontanicznego zachwytu, radości bycia w tym właśnie miejscu, emocjonalnego odczuwania piękna. W Rzymie przebiega między jakimiś pałacami „....nic nie wiem, co to jest, ale mi wszystko jedno, jest wspaniale" [Dz., t. 2, s. 292]. We Florencji wyłamuje się beztrosko spod przymusu oglądania i zachwycania się dziełami sztuki i architektury. Przegapia grób Michała Anioła, troi się jej w oczach, ma katar, kaszel, a wysokie obcasy utrudniają jej chodzenie. Fizyczne zmęczenie i cielesny dyskomfort biorą górę nad scenariuszem stadnych zachowań turysty. Bez fałszywego wstydu Dąbrowska przyznaje się do zmęczenia, bólu nóg i rezygnacji z oglądania wszystkich przepisowych cudów kultury. Włochy nie tylko zachwycają, ale i strasznie nużą, męczą, obezwładniają oraz swoiście terroryzują turystę przymusem pochłaniania niezliczonej ilości wrażeń artystycznych, które pośpiesznie doznawane, wymieszane, nieprzetrawione nie zostawiają żadnego istotnego śladu w poznaniu i doświadczeniu podróżującego. W zjawiskowej, teatralnej Wenecji ważne okazuje się spanie w hotelu pod moskitierą i „pisk moskita, który mnie ugryzł” [Dz., t. 2, s. 288].

Podróż włoską, poprzedzającą pobyt w Jugosławii (1934), skwitowała Dąbrowska skromnie w dziennikach, niejako dla zapamiętania tego biogra- 
ficznego zdarzenia. Okazała się ona ważna nie jako wyprawa turystyczna, nastawiona na cele poznawcze, lecz jako podróż inicjacyjna. Pozwoliła bowiem na wykrystalizowanie się tego, co najistotniejsze i niewzruszone wśród natłoku ogromnych wrażeń, na rozpoznanie własnego powołania jako pisarki i odkrycie koniecznego związku między twórczością a doświadczeniem miłości - fundamentalnego warunku energii twórczej.

Niewątpliwie Jugosławia, a nie Włochy, była dla Dąbrowskiej prawdziwą krainą Południa. Jugosławia to malowniczość, bujność, monumentalność, intensywność, pierwotność, dzikość i porażające piękno. Nazwała ją, przy okazji bytności w zachwycającym Dubrowniku, „zagubioną ojczyzną jakiegoś zakątka mojej duszy" 8 .

W Sarajewie odczuwa Dąbrowska prawdziwe tchnienie Wschodu, fascynujące przemieszanie kultury tureckiej, żydowskiej, europejskiej. Widoki, dźwięki, zapachy układają się w niesamowity, niepokojący i egzotyczny polizmysłowy obraz świata. Składają się nań: oryginalna architektura miasta, zawodzenie muezina $\mathrm{z}$ wieży meczetu, dźwięki kowaczy miedzi w uliczkach, modlitwy na placykach przed meczetem, ablucje wiernych, do tego rozchodzący się zapach kawy i potraw tureckich $\mathrm{z}$ charakterystycznymi przyprawami.

Na wyspie Locrum (1934), wsławionej bytnością nieszczęśliwego cesarza meksykańskiego Maksymiliana Habsburga, intensywny aromat roślin, których liczne nazwy Dąbrowska przywołuje, sprawia, że to miejsce rzuca na przybysza "odurzający czar”. Pytanie, czy umiałaby po zapachu rozpoznać wszystkie te rośliny (mimozy, rozmaryny, mirty, laury, palmy, drzewa pieprzowe, granaty...), czy też informacje o nich zaczerpnęła $z$ jakiegoś przewodnika lub z rozmów z miejscową ludnością? Rosło tam ,jakieś drzewo truskawkowe o bardzo smacznych owocach, rzeczywiście przypominających truskawki". Musiała ich skosztować, wzbogacając swoje doznania zmysłowe o wrażenia smakowe. Że czuła te zapachy to pewne, że złożyły się w jej zmysłowym doświadczeniu na obraz tego miejsca również pewne, ale najważniejsze jest to, że uznała za znaczące i konieczne, by o tym napisać, by zwerbalizować ten wielozmysłowy obraz świata.

Piękna, jeszcze nieskażona cywilizacją wyspa Rab (1936) zachwyca naturalnymi krajobrazami i zapisuje się przede wszystkim $w$ doznaniach zmysłowych Dąbrowskiej, w których sfera dźwięków i zapachów odgrywa pierwszorzędną rolę, choć życie Rabu upływa w wielkiej ciszy. „Gwizdanie kosów rozlega się od świtu do nocy, w mirtach i laurach słowiki śpiewają swe mino-

\footnotetext{
8 M. Dąbrowska, Pisma rozproszone, t. 1, s. 446. Dalej jako P.R., numer tomu i strony bezpośrednio po cytacie.
} 
rowe nokturny, jaskółki tysiącem zygzaków krzyżują się nad zatoką, kukułki kukają gdzieś aż pod murem skał, wilgi odzywają się skąpo, ale donośnie około chłopskich domostw" [P.R., t. 1, s. 428]. Należy zwrócić uwagę na wielką dbałość Dąbrowskiej o walory stylu tekstu pisanego, widoczną w jej skłonności do nadawania obrazowi świata rytmu i ładu poprzez uporządkowanie składni, budowanie serii zdań paralelnych, rytmicznych dzięki zastosowaniu układów trójzestrojowych i wyrazistej organizacji brzmieniowej (instrumentacja głoskowa, rymy). Obecność ludzi też zaświadczają dźwięki: słychać nostalgiczny chóralny śpiew seljaków, tamtejszych pasterzy; ubogi w melodię, ale harmoniczny i wielogłosowy śpiew wioślarzy, ich matowe nawoływania "hallo, hallo, barka", szczebiot dzieci; do tego gra na kobzie i płaskiej drewnianej piszczałce, kołatanie wioseł o dulki łódek, dzwony kościelne i jazzbandy z hoteli tworzą niepowtarzalną aurę dźwiękową tej krainy. Świeże, czyste powietrze, „lekkie do oddychania, lube i ożywcze jak napój podany w chwili pragnienia”, pachnie: „Przesyca je woń morza, długich igieł piniowych, aromat liści figowych, lawendy, siana łączek już pokoszonych" [P.R., t. 1, s. 428]. Promienie słoneczne przyjemnie ogrzewają ciało. Ziemia, niebo, skały, powietrze - widoki, zapachy, odgłosy, doznania cielesne układają się w całość dającą odczucie kosmosu, jakiejś zniewalającej totalności świata. Tak mógłby wyglądać raj.

Na jedyne miasto wyspy patrzy Dąbrowska jak na malowidło. Wiedzę o jego dziejach i zabytkach łączy z wnikliwą obserwacją, by w kunsztownym, stylistycznie wysmakowanym opisie, wykorzystującym poetyckie środki (liczne epitety, porównania, metafory), pokazać w materii miasta znamiona różnych epok. Zwraca uwagę na trzy amfiteatralnie usytuowane ulice „nowego" miasta, położone jedna nad drugą, równoległe i połączone stromymi przecznicami albo schodkami. Puentuje tę rzeczową informację komentarzem: „wszędzie naturalnie w wąskiej smudze błękitu suszy się tu bielizna, jak nanizane rzędami chorągiewki wiecznego festiwalu codzienności" [P.R., t. 1, s. 437-438]. Pierwsza ulica, najniżej położona, na poziomie morza jest cicha i pusta. $Z$ rybackiej winiarni wieje chłodem, zapachem beczek, czasem pieśnią chóralną i żałosną. Składowisko pokruszonych rzymskich pamiątek i obrośnięte dziką zielenią ruiny pałacu Niemirów dopełniają wrażenia pustki.

Druga uliczka, wyżej położona, ogniskuje handel i ruch miasta. Niezwykłą aurę tego miejsca tworzy rozmaitość towarów, „wszystko to lśni, pstrzy się i powiewa", a do tego tłok, miejscowi starzy rybacy z fajkami $\mathrm{w}$ gębie, z bokobrodami á la Franz Joseph, żebracy o brueghelowskich fizjonomiach, wiejskie dziewczyny z koszami muszel i zasuszonych morskich stworów, letnicy. Na trzeciej, najwyższej uliczce można spotkać tylko ska- 
czące dzieci, tam też znajdują się piękne średniowieczne kościoły. W jednym z nich, maleńkim, nie odwiedzanym przez nikogo, barokowym kościółku św. Antoniego Małego lubiła Dąbrowska "dumać i marzyć w pustce kaplicy” [P.R., t. 1, s. 400-401].

Wydawałoby się, że Dąbrowska patrzy na Jugosławię okiem świeżym, czystym i nieuprzedzonym. Decyduje się o niej pisać właśnie dlatego, że nie została ona tak wszechstronnie i dogłębnie przedstawiona, jak Włochy i że jest, jak dotąd, nieskażona współczesną mechaniczną cywilizacją, którą pisarka określa jako „warczącą, ryczącą, dymiącą” [P.R., t. 1, s. 430].

Okazuje się jednak, że pisząc o Jugosławii, a właściwie redagując reportaż do druku w „Wiadomościach Literackich” (1936), przywołuje Dąbrowska kulturowe klisze. To Conrad i jego formy widzenia świata, conradowskie sprzężenie egzotyki i dramatyzmu, owa „surowa tragiczność” w krajobrazie. Innym razem pejzaże Jugosławii nasuwają Dąbrowskiej skojarzenia z rezultatami pracy "mitycznego artysty", w którego majestatycznych dziełach dominuje "czysta forma" - barwna plama i monumentalna bryła. Na wyspie Hvar (zapis w Dziennikach w roku 1960): „Miasto jak malarska kompozycja hiszpańskiego kubisty" [Dz., t. 5, s. 187].

Pejzaż Południa, najpierw Włoch, a potem i przede wszystkim Jugosławii, zostaje rozpoznany przez Dąbrowską jako ucieleśniony kształt marzenia o domu-raju i snu duszy północnej, zdolnej tyleż do zachwytu Południem, ile do wychwytywania w nim rysów "północnych" - melancholijnych i tragicznych. Powtarzają się straszliwe majowe burze, ulewy zmieniają się $\mathrm{w}$ potop, to, "co cieszyło, zaczyna drażnić" [Dz., t. 3, s. 54], Dąbrowska czuje się „obca i światu i na świecie".

Kolejne bytności w Jugosławii, w tych samych miejscach, w ukochanym Dubrowniku i na wyspie Rab owocują innymi obrazami, choć sama Jugosławia nie tak bardzo się zmieniła. Zmieniła się Maria Dąbrowska. W roku 1960, na pięć lat przed śmiercią, czuje się już stara, zmęczona, chora, obca w świecie. Poddaje się zmiennym nastrojom, to euforycznym, to depresyjnym. Pogoda październikowa też jest zmienna. Jest zimno, ciało odczuwa chłodne podmuchy, drażni szum wody, a przerażające wycie wiatru jugo zdaje się być torturą. "Morze chlusta na chodniki przybrzeżne - morze krzyczy - Nie ma w nim tego długiego szumu fali, wykładającej się na piaski - To morze wrzeszczy roztrzaskując się na posępnych skałach" ${ }^{9}$. Widok z fortów Napoleona na wyspie Hvar uprzytamnia jej, że „wybrzeża śródziemnomorskie

\footnotetext{
9 M.Dąbrowska, Dzienniki 1914-1965 w 13 tomach, pierwsze pełne wydanie w 13 tomach (bez opracowania edytorskiego) pod kierunkiem T. Drewnowskiego, t. 12: 1960-1961, Warszawa 2009, s. 142.
} 
są groźne i patetyczne". Pisarka stwierdza „Ja już nic nie napiszę, we mnie pomału zagospodarowuje się śmierć" [Dz., t. 4, s. 97].

Jerzy Giedroyc w Autobiografii na cztery ręce zanotował z niesmakiem, że w czasie pobytu Dąbrowskiej w Szwajcarii „Nie można było z nią rozmawiać na spacerze, bo przystawała przed każdą wystawą i zachwycała się tym, co było w sklepie. Miała reakcje kobiece aż do przesady"10.

Redaktor z Maisons-Laffitte, czerpiący wiedzę o świecie z książek i gazet, okazał się wielce niesprawiedliwy. Nie wiedział, czy nie chciał wiedzieć, że miejska ulica to trakt spacerowy, sposobny do rozmów, ale i do oglądania mijanych ludzi i wystaw sklepowych, wdychania zapachów z knajp i restauracji, łowienia dźwięków z barów, kawiarń, ogródków, sal dansingowych, wsłuchiwania się $\mathrm{w}$ gwar tłumu... Że najlepsze, najbardziej owocne poznawanie miasta odbywa się na ulicy, w trakcie nieśpiesznych przechadzek, obserwacji, rejestracji wrażeń, rozmyślań, refleksji, często wspomnień, rozmów i biesiadowania. Mizoginistyczna niechęć Redaktora do „reakcji kobiecych” zdradza niezrozumienie dla, być może, typowo kobiecego, albo u kobiet intensywniejszego, zmysłowego, polisensorycznego doświadczania świata, które niekoniecznie oznacza niedostatek intelektualnego wyrafinowania.

\section{Maria Dąbrowska in Yugoslavia}

\section{Summary}

This article discusses different forms - in terms of genre - of recording (private letters, diaries, reportage) of Maria Dąbrowska's three journeys to Yugoslavia. In the author's opinion these accounts reveal the tension between the subjective truth of being here and now, which Dąbrowska wanted to express, and the objectivity of being, which she wanted to present objectively. They are also a testimony of a typically female, or rather more intensive in women, polisensory experience of the world.

Keywords: space, journey, senses, narration, Maria Dąbrowska

10 J. Giedroyc, Autobiografia na cztery recce, oprac. i posłowie K. Pomian, Warszawa 1984, s. 186. 